\title{
Varietal performance of Banana under Achalpur condition of Amravati district of Maharashtra State, India
}

\author{
N. H. Ramteke ${ }^{1}$, R. S. Wankhade ${ }^{2 *}$, V. N. Patil ${ }^{3}$ and Y. D. Charjan ${ }^{4}$ \\ ${ }^{1}$ Department of Fruit Science, Dr. P.D.K.V., Akola - 444104, India \\ ${ }^{2}$ Agriculture Research Station, Dr. P.D.K.V., Achalpur Dist. Amravati- 444806, India \\ ${ }^{3}$ Department of Vegetable Science, Dr. P.D.K.V., Akola- 444104, India \\ ${ }^{4}$ Department of Agronomy, Dr. P.D.K.V., Akola-444104, India \\ *Corresponding author
}

\section{A B S T R A C T}

Keywords

Cultivation plant height, stem girth

Article Info

Accepted:

25 January 2019

Available Online:

10 February 2020
An experiment was conducted at Agriculture Research Station, Dr. Panjabrao Deshmukh Krishi Vidyapeeth, Achalpur (M.S.) India to select best suited variety for commercial cultivation under Achalpur condition of Amravati district of Maharashtra state during 2015-16 to 2017-18. Maximum plant height, stem girth, total number of leaves, length of fruit, girth of fruit, number of fruits per bunch, fruit weight, bunch weight and per hectare yield was recorded in Grand naine followed by Shreemanti and Basrai cultivar. Whereas, significantly minimum plant height, stem girth, number of leaves, length of fruit, girth of fruit, fruit weight, bunch weight and yield per hectare was recorded with the variety Pandhari Local.

\section{Introduction}

Banana is one of the most important fruit crops majorly grown in India. It is considered as "poor man's apple". In India, major producing states are Tamil Nadu, Maharashtra, Karnataka, Gujarat, Andhra Pradesh, Assam and Madhya Pradesh. Maharashtra being one of the important states in India growing banana particulary in Jalgaon district. Grand naine is the major variety under cultivation in Maharashtra state.
The area of Banana cash crop is increasing in Achalpur and Anjangaon Surji taluka of Amravati district of Maharashtra State. The choice of suitable variety is of paramount importance for successful commercial cultivation of banana. Some farmers also growing local variety in this area. Hence, with a view to find out suitable variety of banana under this condition, the present experiment was undertaken. 


\section{Materials and Methods}

The experiment was conducted during 201516 to 2017-18 at Agriculture Research Station, Dr. Panjabrao Deshmukh Krishi Vidyapeeth, Achalpur on four varieties viz., Grand Naine, Shrimanti, Basrai and Pandhari Local which were planted in randomized block design (RBD) and replicated five times.

Uniform suckers of all the cultivars were planted during July, 2015-16 to 2017-18 at $1.5 \times 1.5 \mathrm{~m}$ spacing and all plants received uniform dose of NPK (200:40:200g/plant). Observations were recorded on growth and yield regularly and statistically analysed as per the methods given by Panse and Sukhatme (1967).

\section{Results and Discussion}

It is evident from the data presented in Table1, that there were significant varietal differences in respect of growth and yield attributes.

\section{Growth attributes}

The pooled data of three years presented in Table 1 indicated that, the different varieties of banana had recorded significant differences in respect of plant height, stem girth and number of leaves.

Significantly the maximum plant height, girth of stem and number of leaves was noticed in banana varieties viz., Grand Naine (237.33 $\mathrm{cm}, 48.78 \mathrm{~cm}$ and 17.80), followed by Shreemanti $(221.95 \mathrm{~cm}, 45.05 \mathrm{~cm}$ and 16.95$)$ and Basrai $(182.85 \mathrm{~cm}, 44.65 \mathrm{~cm}$ and 15.90$)$. However, significantly minimum plant height was recorded with the variety Pandhari Local $(168.35 \mathrm{~cm}, 38.03 \mathrm{~cm}$ and 15.25$)$.

Such type of varietal variation in banana have been reported by Ahmed et al., (1974),
Shaikh et al., (1985), Medhi (1994), Deshmukh et al., (2004) and Behara et al., (2018).

\section{Yield attributes}

The pooled data presented in Table 1 indicated that, the different varieties of banana had recorded significant differences in respect of fruit length, girth of fruit, number of fruits per bunch, fruit weight, bunch weight and yield per hectare.

Significantly the maximum fruit length, girth of fruit, number of fruits per bunch, fruit weight, bunch weight and yield per hectare was noticed in banana varieties viz. Grand Naine $(20.56 \mathrm{~cm}, 12.65 \mathrm{~cm}, 160.06,183.31 \mathrm{~g}$, $29.34 \mathrm{~kg}$ and $129.11 \mathrm{t} / \mathrm{ha}$ ) followed by Sheemanti $(20.33 \mathrm{~cm}, 12.31 \mathrm{~cm}, 144.75$, $171.94 \mathrm{~g}, 24.89 \mathrm{~kg}$ and $109.51 \mathrm{t} / \mathrm{ha})$ and Basrai $(19.23 \mathrm{~cm}, 11.63 \mathrm{~cm}, 128.50,157.11$ gm, $20.19 \mathrm{~kg}$ and $88.84 \mathrm{t} / \mathrm{ha}$ ).

However, significantly minimum fruit weight was recorded with the variety Pandhari Local $(17.06 \mathrm{~cm}, 11.13 \mathrm{~cm}, 125.50,132.25 \mathrm{gm}$, $16.60 \mathrm{~kg}$ and $73.04 \mathrm{t} / \mathrm{ha}$ ).

The results obtained in respect of yield and yield attributes are in agreement with the results of Syamal and Mishra (1989), Upadhyay and Tripathi (1985), Sharma (1976), Chattopadhyay and Rana (1986), Deshmukh et al., (2004) and Behara et al., (2018).

Keeping the significantly the maximum plant height, stem girth, number of leaves, length of fruit, girth of fruit, fruit weight, bunch weight and yield per hectare were noticed in banana varieties viz. Grand Naine in view, banana cv. Grand Naine can be recommended for commercial cultivation in Vidharbha region of Maharashtra state. 
Table.1 Growth and yield attributes as influenced by different varieties (2015 -16 to 2017-18)

\begin{tabular}{|c|c|c|c|c|c|c|c|c|c|c|c|c|c|}
\hline \multirow{2}{*}{$\begin{array}{l}\text { Sr. } \\
\text { No. }\end{array}$} & \multirow{2}{*}{$\begin{array}{l}\text { Name of } \\
\text { Genotype }\end{array}$} & \multicolumn{4}{|c|}{ Plant Height (cm) } & \multicolumn{4}{|c|}{ Stem Girth (cm) } & \multicolumn{4}{|c|}{ Number of leaves } \\
\hline & & 2015-16 & 2016-17 & 2017-18 & Pooled & 2015-16 & 2016-17 & 2017-18 & Pooled & 2015-16 & 2016-17 & 2017-18 & Pooled \\
\hline 1 & Grand Naine & 243.60 & 244.80 & 246.40 & 237.33 & 43.60 & 56.25 & 57.25 & 48.78 & 13.20 & 21.60 & 24.00 & 17.80 \\
\hline 2 & Shreemanti & 224.40 & 225.60 & 227.20 & 221.95 & 40.80 & 51.75 & 52.75 & 45.05 & 12.60 & 20.60 & 23.20 & 16.95 \\
\hline 3 & Basrai & 152.20 & 196.40 & 198.00 & 182.85 & 40.00 & 51.00 & 52.00 & 44.65 & 11.60 & 19.60 & 22.00 & 15.90 \\
\hline \multirow[t]{5}{*}{4} & $\begin{array}{l}\text { Pandhari } \\
\text { Local }\end{array}$ & 182.40 & 183.20 & 184.20 & 168.35 & 32.20 & 46.75 & 47.75 & 38.03 & 11.00 & 19.00 & 21.40 & 15.25 \\
\hline & F test & Sig. & Sig. & Sig. & Sig. & Sig. & Sig. & Sig. & Sig. & Sig. & Sig. & Sig. & Sig. \\
\hline & SE $\mathbf{m} \pm$ & 4.236 & 4.189 & 4.117 & 7.322 & 0.941 & 0.717 & 0.717 & 0.602 & 0.379 & 0.362 & 0.356 & 0.060 \\
\hline & C.D. 5\% & 13.050 & 12.906 & 12.685 & 22.559 & 2.899 & 2.210 & 2.210 & 1.854 & 1.168 & 1.116 & 1.098 & 0.184 \\
\hline & & \multicolumn{4}{|c|}{ Length of fruit (cm) } & \multicolumn{4}{|c|}{ Girth of fruit (cm) } & \multicolumn{4}{|c|}{ Number of fruits per bunch } \\
\hline 1 & Grand Naine & 20.25 & 20.50 & 21.50 & 20.56 & 12.50 & 12.75 & 13.10 & 12.65 & 158.29 & 161.75 & 160.20 & 160.06 \\
\hline 2 & Shreemanti & 20.00 & 20.25 & 21.25 & 20.33 & 12.00 & 12.25 & 12.75 & 12.31 & 145.75 & 143.50 & 142.75 & 144.75 \\
\hline 3 & Basrai & 19.00 & 19.00 & 20.00 & 19.23 & 11.50 & 11.25 & 12.00 & 11.63 & 129.20 & 128.75 & 127.5 & 128.50 \\
\hline \multirow[t]{5}{*}{4} & $\begin{array}{l}\text { Pandhari } \\
\text { Local }\end{array}$ & 17.00 & 18.00 & 16.00 & 17.06 & 11.00 & 11.00 & 11.50 & 11.13 & 130.50 & 135.25 & 122.75 & 125.50 \\
\hline & F test & Sig. & Sig. & Sig. & Sig. & Sig. & Sig. & Sig. & Sig. & Sig. & Sig. & Sig. & Sig. \\
\hline & SE $\mathbf{m} \pm$ & 0.525 & 0.371 & 0.371 & 0.304 & 0.183 & 0.192 & 0.150 & 0.077 & 0.536 & 0.458 & 0.281 & 3.646 \\
\hline & C.D. 5\% & 1.622 & 1.142 & 1.142 & 0.936 & 0.562 & 0.592 & 0.461 & 0.238 & 1.651 & 1.411 & 0.867 & 11.231 \\
\hline & & \multicolumn{4}{|c|}{ Fruit weight (g) } & \multicolumn{4}{|c|}{ Bunch weight (kg) } & \multicolumn{4}{|c|}{ Fruit yield of Banana ( $t /$ ha) } \\
\hline 1 & Grand Naine & 182.75 & 184.00 & 183.50 & 183.31 & 28.93 & 29.75 & 29.40 & 29.34 & 127.28 & 130.94 & 129.35 & 129.11 \\
\hline 2 & Shreemanti & 172.75 & 170.20 & 171.75 & 171.94 & 25.18 & 24.43 & 24.52 & 24.89 & 110.78 & 107.47 & 107.88 & 109.51 \\
\hline 3 & Basrai & 157.50 & 157.5 & 154.20 & 157.11 & 20.38 & 20.28 & 19.64 & 20.19 & 89.67 & 89.22 & 86.40 & 88.84 \\
\hline \multirow[t]{4}{*}{4} & $\begin{array}{l}\text { Pandhari } \\
\text { Local }\end{array}$ & 132.50 & 132.00 & 131.25 & 132.25 & 17.33 & 17.80 & 16.11 & 16.60 & 76.22 & 78.58 & 70.88 & 73.04 \\
\hline & F test & Sig. & Sig. & Sig. & Sig. & Sig. & Sig. & Sig. & Sig. & Sig. & Sig. & Sig. & Sig. \\
\hline & SE $\mathrm{m} \pm$ & 0.657 & 0.857 & 0.490 & 0.544 & 0.119 & 0.112 & 0.087 & 0.584 & 0.522 & 0.495 & 0.381 & 2.572 \\
\hline & C.D. 5\% & 2.024 & 2.642 & 1.508 & 1.677 & 0.366 & 0.347 & 0.267 & 1.801 & 1.608 & 1.526 & 1.174 & 7.923 \\
\hline
\end{tabular}




\section{References}

Ahmed, K. , Hossain A.K. and Hossain, B. (1974). A comparative study on four table varieties of banana. Bangladesh Hort., 2 (1): 5·11.

Behara S., M.K. Patel, C. M. Panda and Das B.K. (2018). Assessment of genetic diversity of culinary banana based on morphological characters. The Pharma Innovation Journal. 7(8):12-14.

Chattopadhyay, P. K. and Raha, S. R. (1986). Physico chemical composition of some important banana varieties of west Bengal. Haryana J. Hort. Sci., 15 : 170 $-174$.

Deshmukh, S. S., C. D. Badgujar and S. M. Dusane (2004).Comparative evaluation of banana varities under Jalgaon condition of Maharastra state. Agriculture Science Digest, 24 (2): 118-
20.

Medhi, G. (1994). Performance of some cultivars of Banana (Musa paradisiaca) in Assam. Haryana J. of Hort. Sci, 23(3) : 181-185.

Panse, V.G. and Sukhatme, P. V. (1969) Statistical Methods for Agricultural Workers, 2 nd Edition, ICAR, New Delhi.

Shaikh, M. R. et al., (1985). Pakistan J. Agric. Res., 62:189-191.

Sharma, D. D. (1976).Varietal differences in the physico-chemical characteristics of banana fruit. Indian Agric., 20 : 115119.

Syamal, M. M. and Mishra, K. A.(1989). Studies on some dessert banana (Musa Sapientum L.) cultivars. Indian J.Hort., $46: 316-318$.

Upadhyay,N.r.and Tripathi,B.M.(1985). Prog.Hort., 17:91-94.

\section{How to cite this article:}

Ramteke. N. H, R. S. Wankhade, V. N. Patil and Charjan. Y. D. 2020. Varietal performance of Banana under Achalpur condition of Amravati district of Maharashtra State, India. Int.J.Curr.Microbiol.App.Sci. 9(02): 3104-3107. doi: https://doi.org/10.20546/ijcmas.2020.902.358 